\title{
Order in the Eurozone: MAURIZIO FERRERA and CLAUS OFFE in Conversation
}

VB verfassungsblog.de/order-in-the-eurozone-maurizio-ferrera-and-claus-offe-in-conversation/

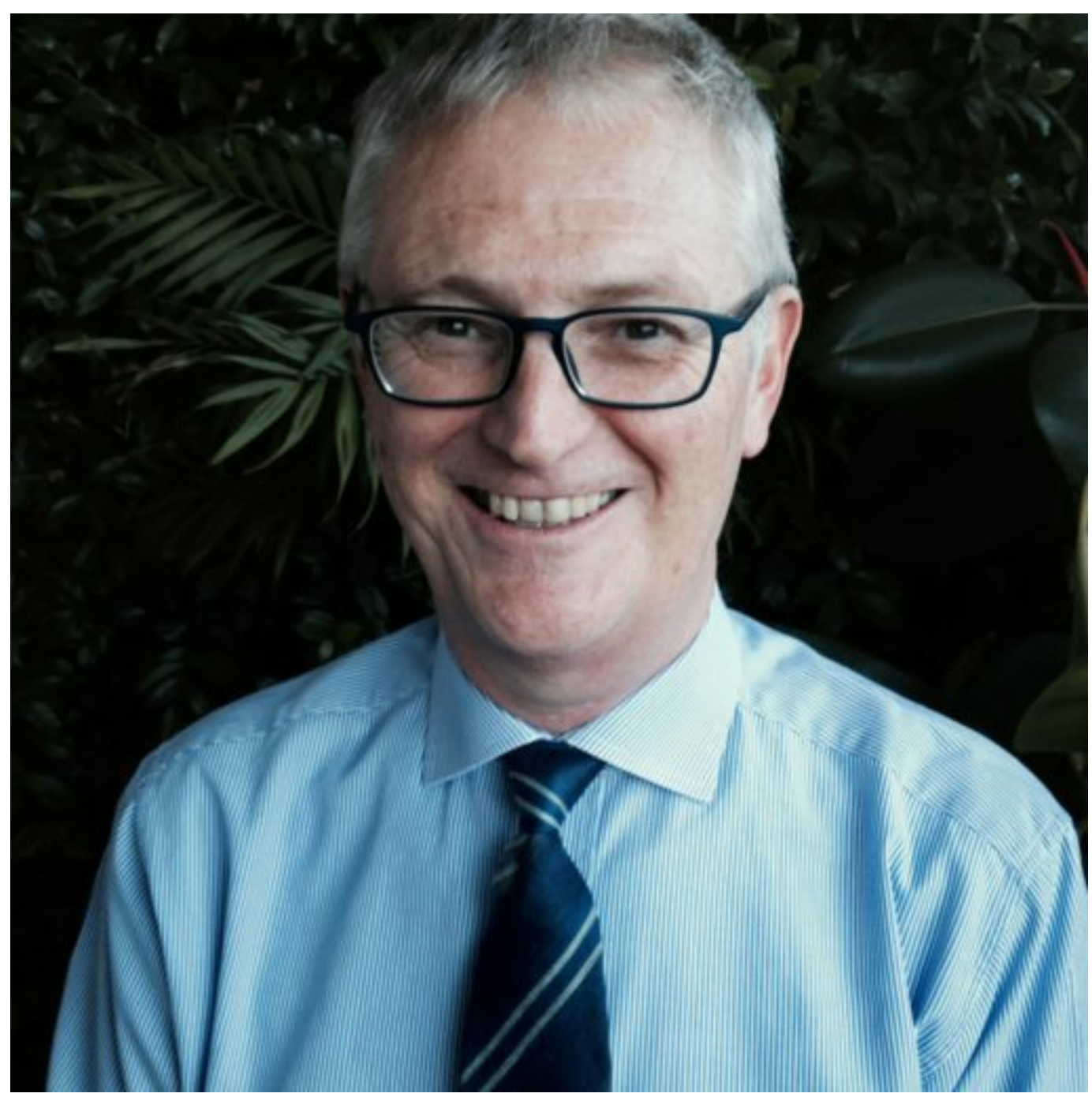

MF: You have recently written a lot about Europe and the increasing North-South divides within the Eurozone. You are also one of the few influential German intellectuals who openly criticizes German governments and their orientations on EMU. Do you see a nexus between the EMU's dysfunctionalities and the social and political crisis, especially in Southern Europe?

CO: Yes, I certainly do. The monetary regime of the Euro under which 19 very diverse national economies within the EU now live and operate is plainly dysfunctional. It does not serve its alleged and promised purpose of convergence but does the exact opposite. It is economically and politically divisive: Some participants win, others lose and the gap becomes wider.

The Euro ties the hands of the losers, roughly the Mediterranean region of the EU. They can no longer adjust to challenges of competitiveness by devaluing their national currency because there is none any more. If they need to adjust, they must do so "internally", i. e. by depressing wages, pensions, and state (in particular welfare) expenditures, all of which is 
detrimental to growth, employment, and the prospects of reducing public debt through a fiscal dividend resulting from growth. Today, Italian GDP per capita is still 8 per cent below of what it was in 2008. Yet that does not seem to be enough to boost Italian unit costs of labor, the key determinant of competitiveness in international trade. The living conditions of ordinary people have been severely depressed, giving rise to discontent, resentment and angry if often misdirected protest. Loser economies are no longer allowed, under the EMU regime, to set their targeted rate of inflation because that is done by the ECB. At the same time, the extremely low interest rate, also determined by the $\mathrm{ECB}$, benefits the winners by making their public debt easier to service. For instance, experts speak of 294 billion Euros, a figute that comes close to an annual Federal budget, that the German public debt burden has been made lighter since 2007 through low interest rates. Another way in which the Euro benefits winner countries is that it works as an export subsidy due to its uniform external exchange rate. Absent the Euro, the new Deutschmark would dramatically appreciate its exchange rate with the outside world and German export industries would largely collapse as a consequence. No wonder that winners such as, most of all, Germany indulge in their obsessions with automatic rules and austerity. Yet the German government does not show any inclination to share this windfall profit with those whose plight has indirectly given rise to it. This all looks like what the Hungarian-born historian Karl Polanyi, referring to the "veritable abyss of human degradation" that occurred under early capitalism, has called a "satanic mill". One feature that makes the mill particularly "satanic" is the fact that nobody, neither losers nor winners, can rationally (and actually does in earnest) opt for leaving the Euro. Unilateral exit from the EMU is, in spite of some demagoguery to the contrary, a plain non-starter due to the huge damages exiteers would have to cope with as a consequence. Unless there is a way to reform and to some fair compensation of losers, we remain trapped in the "mill". Yet the longer it operates and inflicts damages on losers and grants profits to winners, the harder it becomes politically to embark on a serious path of reform that opens a credible prospect of convergence. Such reform, together with winners funding large scale border-crossing investments programs, remains the only collectively rational way out. But for charting such path time may be running out.

MF: This logic was partly there from the beginning of EMU. Don't you think that some institutional reforms introduced in the early 2010s - such as the Fiscal Compact, the strengthening of supranational controls and conditionality, the adoption of democratic "monsters" such as reverse qualified majority rule for macro-economic and fiscal decisions - have severely aggravated EMU's dysfunctionality?

CO: Absolutely. The new tools of enforcing "discipline", austerity and control are widely recognized to be counterproductive in their effects. But they are the only tools the EU, driven by a constant and no doubt realistic fear of the disasters the "markets" may inflict upon its stability, has at its disposal and which are within the reach of the intergovernmental making of treaties between EU member states. They confirm the image of "Brussels" as an illegitimate foreign power imposing rules without being itself subject to democratic accountability. We now have a rich evidence in Europe of the electoral outcomes to which this economic and monetary regime gives rise. The EU lacks the requisite state capacity to deal with the partly disastrous consequences caused by the operation of its monetary system. If the EU were a federal state, and a democratic federal state at that, it would have 
at its disposal the governing capacity to tax and to redistribute its resources across state borders and compensate losers for at least parts of their systematically generated losses. In its present institutional shape, it is still far from having the authority to do so.

MF: The obvious question is then: cui prodest? Who are, let us name then, the EMU winners? And do you think there was a deliberate power strategy?

CO: As I said, Germany has been the main beneficiary of the institutional architecture and measures that were put in place since 2008. That fact need not be due to what you call a "deliberate power strategy" or conspiracy of sorts. Power, as political scientist Karl Deutsch has famously pointed out, is the ability to afford not to learn. In that sense German power consists in the unwillingness of German political elites (as well as, it must be added, major parts of ill-informed non-elites) to promote and adopt reforms needed to remedy the worst institutional pathologies of the EMU. Such reforms are not only affordable for one of the biggest and currently one of the wealthiest economies of the Eurozone; they are even dictated by its long term and well-considered interest in making the EMU a robust and inclusive monetary regime.

MF: As the largest Member State and as the economic powerhouse of Europe, one would expect Germany to somehow serve as a benign hegemon, capable of reconciling her own national interests with the interests of others and especially with the long term economic and political sustainability of the EU

CO: During the long crisis Germany has in fact largely abdicated its responsibility in and for Europe. The German government's obsession with rules, austerity and conditionality has been the main driving force behind the growing divergence of EMU economies and the devastating social shocks which has hit Southern member states. Germany has tried to push through her own economic and social model, based on flawed assumptions that we might call a "flower pot theory". Such theory is the favorite mode of thinking of winners. Their message: the rules that have worked so advantageous in "our" case are the same that would work to the benefit of "you" as well - if only you could overcome yourself to follow "our" rules which you are most welcome, in fact required, to adopt and follow. Flowers in separate flower pots develop similarly if you use the same seeds, the same fertilizers etc. What is wrong with this comfortable mode of thinking is that it ignores and denies systemic interdependence. However, there is a powerful intellectual antidote. It is captured in a sentence by authors Mathijs and Blyth, often quoted in the scholarly literature on the EU. It reads: "The Eurozone as a whole cannot become more like Germany. Germany could only be like Germany because the other countries were not." Germany is like Germany, we might add, because of its reaping of unreciprocated advantages from the system of EU member states and their interdependencies - the opposite of separate flower pots.

MF: In the flower pot theory a key role is played by rules and decision making procedures. The motto of German and Northern elites during the crisis has been pacta sunt servanda. That is fair enough. But Roman law foresaw an additional clausola rebus sic stantibus: treaty obligations can remain unfulfilled due to a compelling change in circumstances. Only 
the jus cogens based on basic principles was peremptory, with no possibility of derogation.... Can we say that such rather obvious distinctions have been forgotten during the crisis - or possibly even in the original design of EMU?

$\mathrm{CO}$ : This question takes us into the difficult field where we must explore the relation between rules and decisions. Rules of social and political life are not in any sense "given"; they are man-made and have been adopted at some point by decision. Following rules as a matter of routine can be a highly efficient way to avoid the need to make decisions. But social agents can also decide to break rules rather than comply with them, and sometime there are even good and justifiable reasons for doing so, e. g. when the rebus sic stantibus proviso does not apply. For instance, the rules may be biased and favor one of the conflicting parties to which they apply. Nota bene: uniform rules do not create a level playing field. Absent such reasons, there are reasons to enforce rules. But efforts at enforcement can fail, or it can involve the violation of other rules. It all boils down to the issue of how we judge the quality of those respective reasons. This conflict may be resolved by bending or temporarily suspending rules in order to avoid having to break them, or by reforming them. Insisting on rules being valid once and forever can be an attitude that is driven by self-interest of those whom the rules favor rather than an attitude inspired by sincere respect for the rules. As we easily recognize, each of these ramifications play a role in the day-to-day discourse and conflicts over European integration and Eurozone politics.

MF: Another shibboleth of neoliberal doctrine is that we cannot separate control and liability: whoever decides to do something must be solely held responsible for its consequences. This is simply poor sociology. In a complex system such as EMU is it still possible to determine with any politically relevant precision those effects which can be traced back to domestic policy decisions and therefore implicate national "responsibility"? Moreover, it is in the nature of all social interaction that we are not rewarded for all positive effects we cause for others, nor are we bound to compensate others for all the negative externalities we cause for them. Of course I am not denying that there are numerous policy areas in which domestic decision still make the difference and therefore do implicate national responsibility. And we know that some governments even cheated Brussels when the crisis erupted. But don't you think that the rhetoric of "saints" and "sinners" espoused by German leaders (including social, media and intellectual elites) has grown beyond limits of epistemic, moral and political acceptability?

CO: I couldn't agree more. Again, the questions takes us into the field of legal philosophy. To what extent can actors alone be held responsible for the misfortune they suffer or the gains they achieve? Again, winners tend to ascribe their profit to their own talents and efforts, while losers like to frame themselves as victims of adverse circumstances. Winners depict losers as having failed to obey the commands of prudence and moral consistency, while losers look at winners as having benefitted from sheer luck or the uncompensated help of others. These conflicting narratives must be checked case by case for their relative merits, and care must be taken that the narratives of winners do not prevail over other narratives and frames, as they often tend to do in the multilingual and hence fragmented public sphere of the EU.

The German framing of the problem of the EMU and the EU is often described and 
criticized as an obsession with "order". In fact, the economic policy doctrine of "ordo liberalism" that was canonized by committed protestant professors and politicians in the early post-war period of the Federal Republic is inspired by the deep intuition that a stable and robust social order is best built when rules are irreversibly put in place and decisions and discretionary interventions - be it by corporate actors or political authorities - are banned or kept to a minimum. This doctrine has always reminded me of a story told by Bertolt Brecht in his collection of anecdotal sketches called Flüchtlingsgespräche (conversations of refugees [from Nazi Germany in the 1930s]). One is a physics professor, the other a metal worker. The latter concludes their conversation on the nature of order by musing: "We might put it this way. Where nothing is in its right place, there is disorder. Yet order is where in the right place there is nothing." The professor agrees: "Order is a phenomenon of something missing." Just to illustrate: As reported in a recent comment in the Financial Times (May 6, 2018), one paragon of fiscal probity and austerity, namely Nicolae Ceausescu, the Romanian dictator, boasted a budget surplus of 9 billion dollar in 1989. By the end of that year, his regime had suddenly collapsed and he was no longer among the living.

This conversation took part on the occasion of the conference "Responses of European Economic Cultures to Europe's Crisis Politics: The Example of German-Italian Discrepancies" on 25-27 June 2018 at Villa Vigoni, convened by Christian Joerges (Hertie School of Governance, Berlin) and Josef Hien (Universitá degli Studi, Milan) and supported by DAAD.

\section{LICENSED UNDER CC BY NC ND}

SUGGESTED CITATION Ferrera, Maurizio; Offe, Claus: Order in the Eurozone: MAURIZIO FERRERA and CLAUS OFFE in Conversation, VerfBlog, 2018/7/13, https://verfassungsblog.de/order-in-the-eurozone-maurizio-ferrera-and-claus-offe-inconversation/. 